\title{
Konzentrationslager Buchenwald, Post Weimar (w literaturze polskiej)
}

Arkadiusz Morawiec

TEKSTY DRUGIE 2020, NR 3, S. 198-212

DOI: 10.18318/td.2020.3.13 | ORCID: 0000-0001-6424-1194

Mniej więcej po dwóch dniach jazdy przerywanej postojami - stacja Weimar. Ktoś mówi... Goethe... ktoś drugi: to chyba jednak Buchenwald.

Adolf Gawalewicz Refleksje z poczekalni do gazu'

D ysponujemy kilkoma opracowaniami dotyczącymi polskiej literatury tworzonej w poszczególnych niemieckich obozach koncentracyjnych, m.in. w Auschwitz, Buchenwaldzie i Mauthausen-Gusen². Brakuje natomiast, poświęconych konkretnym kacetom, ujęć tematologicznych, obejmujących utwory zarówno komponowane w obozie, jak i tworzone poza nim. Niniejszy artykuł stanowi próbę takiego „monograficznego" ujęcia

1 A. Gawalewicz Refleksje z poczekalni do gazu. Ze wspomnień muzułmana, Wydawnictwo Literackie, Kraków 1968, s. 97.

2 A. Lebda-Wyborna Poezja powstała w KL Auschwitz, "Zeszyty Oświęcimskie" 1975, nr 16, s. 5-69; M.I. Sacha "Gdyście w obóz przybyć już raczyli...". Obraz kultury lagrowej w świadectwach więźniów Buchenwaldu 1937-1945, Instytut Pamięci Narodowej, Bydgoszcz-Gdańsk 2014; S. Dobosiewicz Mauthausen-Gusen. Poezja i pieśń więźniów, Pax, Warszawa 1983.
Arkadiusz Morawiec

- prof. dr hab., literaturoznawca i krytyk literacki, zatrudniony w Instytucie Filologii Polskiej i Logopedii Uniwersytetu Łódzkiego. Zajmuje się historią literatury polskiej XX i XXI wieku, zwłaszcza literaturą obozową i literaturą ludobójstwa (w tym Holokaustu) oraz pisarstwem jako formą pamięci. Opublikował między innymi książki: Literatura w lagrze, lager w literaturze. Fakt - temat - metafora (2009) i Literatura polska wobec ludobójstwa. Rekonesans (2018). Kontakt: arkadiuszmorawiec@ poczta.fm 
Konzentrationslager Buchenwald (którego oficjalną nazwę dopełniała formuła: Post Weimar). Wydobyte z obfitego polskiego piśmiennictwa lagrowego utwory tematyzujące ten obóz, wszelako nie wszystkie, ograniczam się bowiem do tekstów reprezentatywnych ${ }^{3}$, ujmuję chronologicznie, sytuując je w kontekście historycznym, politycznym i ideologicznym, nie przeoczając przy tym, rzecz jasna, ich wymiaru estetycznego.

Do najwcześniejszych dokonań literatury polskiej zawierających motyw nazistowskich obozów koncentracyjnych należą wiersze satyryczne Władysława Szlengla, z niepokojem i raczej bez nadziei przyglądającego się temu, co dzieje się w hitlerowskich Niemczech. Jeden z nich, Uroczystość made in Germany z 1938 roku, poprzedza odautorska nota: „W Buchenwaldzie pod Weimarem otwarto nowy obóz koncentracyjny. Proponuję następującą mowę dla ministra propagandy". Zamysłem Szlengla jest tutaj wyszydzenie prowadzonej przez niemiecki rząd polityki represji, oparte na dość udanym koncepcie: „Europa się dziwi - Europa się krzywi, / że ludzie w Niemczech są dziś nieszczęśliwi, / że się wszystko zamyka, że wszystko zamiera, / przepraszam - właśnie otwieram... / [...] / Dla wszystkich wygnanych, przepędzonych, / bitych, dławionych i grabionych / za zdeptaną wartość i talent / dajemy ekwiwalent. / Wygnanie, udręka - to pozór, / wszystkich przygarniam TU, / TU, DO NOWEGO OBOZU...”" . O tym, co działo się w „nowym obozie”, polscy czytelnicy mogli dowiedzieć się od byłych więźniów, i to całkiem wcześnie. Mam na myśli dwie publikacje z 1939 roku: tom reportaży Stanisława Nogaja Za drutami i kratami Trzeciej Rzeszy oraz wspomnienia Władysława Wójcika Byłem w piekle... Pierwsza z nich opiera się na relacjach Polaków i Niemców zwolnionych z obozów. Cztery spośród siedmiu zaprezentowanych reportaży dotyczą Buchenwaldu. Zawierają liczne szczegóły na temat funkcjonowania obozu, również ten, że więziono w nim Polaków już przed wojną. Tenże fakt potwierdzają wspomnienia Wójcika, który trafił do Buchenwaldu z powodu przekroczenia przepisów o ruchu granicznym. Jego tekst informuje i zarazem przestrzega. Obie te funkcje anonsowane są w skierowanym do autora przez współwięźnia, wycieńczonego Żyda, nakazie: ,jak znajdziesz się na wolności, nie zapominaj głosić tego, co tu widziałeś, to jest twoim

3 Artykuł jest fragmentem przygotowywanej monografii poświęconej polskiej literaturze obozowej.

4 W. Szlengel Uroczystość made in Germany, "Robotnik” 1938, nr 186, s. 5.

5 S. Nogaj Za drutami i kratami Trzeciej Rzeszy. Reportaże, t. 2, nakł. Stanisław Szarłata, Katowice 1939. 
świętym obowiązkiem, przez to możesz uchronić tysiące ludzi od okropnej śmierci" ${ }^{\prime \prime}$. Przed zwolnieniem z obozu Wójcik i jego towarzysz otrzymują od esesmana radę: "nie macie po co do Polski jechać; niedługo znowuż będziecie internowani jako jeńcy wojenni"7. Zawierający te słowa (ostatni) odcinek wspomnień ukazał się 1 września, w dniu wybuchu II wojny światowej. Od tej chwili, istotnie, niemieckie stalagi i oflagi zaczęły zapełniać się polskimi jeńcami. Więźniów z Polski poczęły też wchłaniać obozy koncentracyjne, w tym Buchenwald ${ }^{8}$.

Wśród wybitnych lub znanych europejskich pisarzy, których więziono w KL Buchenwald i którzy dali literacki wyraz temu doświadczeniu, znajdują się Jean Améry, Bruno Apitz, Imre Kertész, Arnošt Lustig, David Rousset, Jorge Semprún, Ernst Wiechert, Elie Wiesel. Najbardziej znaczący polscy twórcy literatury lagrowej, tacy jak Tadeusz Borowski, Gustaw Morcinek czy Seweryna Szmaglewska, byli dręczeni w innych obozach. Nie znaczy to jednak, że literatura polska nie ma z podweimarskim obozem nic wspólnego. Jego więźniami byli tacy, początkujący w chwili aresztowania, autorzy, jak Jan Maria Gisges czy Marian Kubicki. W Buchenwaldzie pisarzem stał się Edmund Polak. Utwory, głównie wiersze, tworzyli tutaj Stanisław Grudziński, Stanisław Kisiel i wielu innych ${ }^{9}$. O niektórych niewymienionych tutaj będzie jeszcze mowa.

W zrodzonej w Buchenwaldzie literaturze polskiej dominuje poezja. Jej kluczową tradycję stanowi liryka romantyczna (dobrze widoczna w utworach Zygmunta Lubicz-Zaleskiego) ${ }^{10}$ i młodopolska (aktualizowana m.in. przez Mieczysława Lurczyńskiego) ${ }^{11}$, natomiast dominującą kategorią estetyczną

6 W. Wójcik Byłem w piekle... Lublinianin w niemieckim obozie koncentracyjnym w Buchenwaldzie, "Głos Lubelski" 1939, nr 233, s. 5.

7 W. Wójcik Byłem w piekle..., "Głos Lubelski” 1939, nr 239, s. 5.

8 Pierwsze dwa transporty z obszaru Polski podbitego przez III Rzeszę przybyły do Buchenwaldu 15 i 16 października 1939 roku. Zob. W. Czarnecki, Z. Zonik Walczący obóz Buchenwald, Książka i Wiedza, Warszawa 1969, s. 51.

9 Zob. tamże, s. 394-397, 402-403; C. Ostańkowicz Straszna Góra Ettersberg, Wydawnictwo Łódzkie, Łódź 1968, s. 34-35, 94-97; M.I. Sacha "Gdyście w obóz przybyć już raczyli..." (w książce tej znajduje się obszerna Antologia tematyczna polskiej i niemieckiej liryki obozu koncentracyjnego Buchenwald i podobozu HASAG-Leipzig, s. 347-480).

10 Z. Lubicz-Zaleski Relikwiarz buchenwaldzki, Volumen, Société Historique et Littérairie Polonaise, Warszawa-Paryż 2016. 
jest patos. Większość liryki buchenwaldzkiej jest pod względem artystycznym słaba, najwyżej przeciętna. Teksty nieszablonowe zdarzają się tylko wyjątkowo. Należy do nich np. bezpretensjonalna, wystylizowana ludowo Krowia dola Edmunda Polaka, będąca wymowną alegorią losu więźniów: „Idą krowy drogą, idą, / ano - cóż? / wychudzone, nędza z bidą, / za krowami - kurz. // Jak to u nich we zwyczaju, / przystanęły na rozstaju / trawę gryźć. // Taka to już krowia dola - / żreć, a iść"12. Walory estetyczne nie były jednak w przypadku tej twórczości najbardziej istotne. Ważniejsza okazywała się funkcja psychospołeczna i dokumentująca. Oprócz więc utworów, w których świat przedstawiony stanowi formę ucieczki od obozowego koszmaru we wspomnienia lub do świata przyrody, ekspresję tęsknoty do ojczyzny i osób bliskich, słowem, oprócz swego rodzaju „poezji czystej” znajdujemy utwory, których tematem jest obóz ujmowany we wszelkich możliwych aspektach, takich jak praca, głód czy śmierć. Często wzmiankowany bywa, rosnący obok kuchni dla więźniów, „dąb Goethego", pod którym, wedle tradycji, autor Fausta zwykł siadywać, rozmyślać i tworzyć poezję. W Buchenwaldzie powstawały również, jakkolwiek sporadycznie, utwory prozatorskie. Nie zostały one opublikowane. Jest wśród nich dłuższy tekst Tadeusza Korab-Kucharskiego Czarny ekran, kilka prób nowelistycznych Edmunda Polaka o tematyce wolnościowej i kilkanaście felietonów Zygmunta Zonika; poza tym podjęto nieliczne próby prowadzenia dziennika ${ }^{13}$. W 1944 roku Edmund Polak skomponował dla tajnej sceny polskiej w KL Buchenwald, wzorowaną na Weselu Stanisława Wyspiańskiego, sztukę sceniczną Przebudzenie. Jej akcja, rozgrywająca się w obozie, wyjaśniała przyczynę wywołania i upadku powstania warszawskiego. Wystawienie tego utworu, do którego ostatecznie nie doszło, miała poprzedzać prezentacja (nieznanej z tytułu) sztuki Edwarda Stankiewicza ${ }^{14}$.

Na tym tle jako tekst oryginalny jawi się dramat Stara Gwardia Mieczysława Lurczyńskiego. Według zapewnień zawartych w poprzedzającym go odautorskim wstępie, powstawał on w lagrze (ukazane realia sugerują, że raczej w komandzie „Hecht” w Eschershausen niż w obozie macierzystym). Ukazał się w 1946 roku w Hanowerze ${ }^{15}$. Utwór ten sytuuje się „po stronie” Tadeusza Borowskiego, tj. jego opowiadań, traktowanych w Polsce jako intelektualny

\footnotetext{
E. Polak Krowia dola, „Wolni Ludzie” 1947, nr 2, s. 3.

Zob. W. Czarnecki, Z. Zonik Walczący obóz Buchenwald..., s. 397.

Zob. E. Polak Morituri, Czytelnik, Warszawa 1968, s. 174-178.

M. Lurczyński Stara Gwardia, Polski Związek Wychodźstwa Przymusowego, Hanower 1946.
} 
i artystyczny probierz literatury lagrowej i zarazem jej najwybitniejsze dokonanie. (Drugim jej biegunem jest, jak wiadomo, tzw. literatura martyrologiczna, często schematyczna, tendencyjna, niepobudzająca intelektualnie). Lurczyński demaskuje w Starej Gwardii, czyniąc to wcześniej niż Borowski czy Primo Levi, uproszczony obraz lagru, oparty na schemacie kata i ofiary. Innym atutem tego utworu jest język, wystylizowany na lagerszprachę, pełną wulgaryzmów, w której wyraża się system wartości narzucony przez obóz. $\mathrm{Na}$ temat genezy i funkcji dramatu, ujawniając przy tym jego problematykę, autor wypowiedział się po latach następująco:

Musiałem powiedzieć prawdę, chociażbym miał spalić się razem z nią. Obóz to nie było tylko cierpienie, nie był tylko ból, śmierć, głód, chłód, tortura, krematorium, choroby, praca niewolnicza, nagość w mogilnym dole. To była również hańba własnego poniżenia za cenę próby ocalenia życia, to była współpraca w ciemiężeniu innych, to było popychanie innych do grobu celem uzyskania szansy przeżycia dla siebie. [...] Miałem oryginalne notatki z obozu. Dosłowne teksty wypowiadanych zdań, zapisane charakterystyczne gesty, poczynania, odruchy, reakcje. [...] ten materiał, który miałem zanotowany, trzeba było tylko uporządkować, oprawić w ramę sztuki teatralnej, uczynić z niej rodzaj zwierciadła, w którym by się mógł przejrzeć model. Niech ludzie sądzą. ${ }^{16}$

Zanim Lurczyński opublikował swój dramat, trzy poświęcone Buchenwaldowi utwory ukazały się w 1945 roku w polskiej prasie. Są to: opowiadanie Juliana Podoskiego Człowiek z trzech obozów, anonimowa opowieść Trzy lata w niemieckich obozach koncentracyjnych oraz wspomnienie zatytułowane $O \mathrm{deq}$ bie Goethego w obozie buchenwaldzkim, którego autorem jest prawdopodobnie Ludwik Fleck, wybitny biolog i filozof nauki ${ }^{17}$. Wszystkie one, niepozbawione znamion literackich (niestety, niewysokiej próby), aktualizują patriotyczny, martyrologiczny i parenetyczny wzorzec, w którym pierwszoplanowe role

16 M. Lurczyński Reszta jestmilczeniem, Polska Fundacja Kulturalna, Londyn 1988, s. 49-50. Szerzej na temat Starej Gwardii zob. A. Morawiec Literatura w lagrze, lager w literaturze. Fakt - tematmetafora, Wydawnictwo Akademii Humanistyczno-Ekonomicznej, Łódź 2009, s. 149-177.

17 J. Podoski Człowiek z trzech obozów, "Dziennik Polski” 1945, nr 78, s. 2-3; Trzy lata w niemieckich obozach koncentracyjnych. Więzień Buchenwaldu opowiada, oprac. Piw., "Głos Ludu” 1945, nr 165, s. 4; Więzień Nr 4935 [L. Fleck?] O dębie Goethego w obozie buchenwaldzkim, "Sztandar Ludu" 1945, nr 223, s. 5. 
odgrywają szlachetni Polacy oraz, skontrastowani z nimi, zdegenerowani Niemcy.

Buchenwald jako temat, a raczej pretekst, zyskał na znaczeniu w Polsce w okresie stalinizmu. Prawdy i mity dotyczące tego obozu zaprzęgnięto wówczas do walki ideologicznej wymierzonej przeciwko zachodnim imperialistom, „faszystom” i kapitalistom. Służyły one zarazem legitymizacji władzy komunistów w Polsce, NRD i innych krajach bloku wschodniego. Istotnym zabiegiem było w tym przypadku eksponowanie bez wątpienia kluczowej roli, jaką w buchenwaldzkim ruchu oporu odegrali komuniści. Podkreślano, zgodnie z prawdą, że przyczynili się oni do złagodzenia terroru ze strony załogi obozowej, a także, co w przypadku niemieckich obozów koncentracyjnych stanowi wyjątek, dokonali jego wyzwolenia ${ }^{18}$.To ostatnie - dopowiedzmy - nie ziściłoby się jednak bez udziału wojsk amerykańskich (co z reguły w owym czasie przemilczano).

Najbardziej wymownym literackim przejawem tych tendencji jest opublikowane w 1949 roku opowiadanie Rekord Tadeusza Borowskiego, wówczas gorliwego stalinisty i socrealisty. Bohaterami utworu są: Frau Elza, oczekująca na proces zbrodniarka wojenna, i mający nad nią pieczę komendant amerykańskiego więzienia. Fabuła została osnuta wokół głośnej sprawy Ilse Koch, żony komendanta KL Buchenwald, którą w 1947 roku amerykański sąd skazał na dożywocie. Wcześniej jednak, przebywając w areszcie, zaszła ona w ciążę; odbywając zaś wyrok, urodziła syna. W związku z tym w 1948 roku Amerykanie zredukowali jej karę do czterech lat pozbawienia wolności. Wywołało to protesty. Pod koniec 1949 roku wszczęto więc kolejny proces, tym razem uczyniły to władze zachodnioniemieckie. Koch ponownie skazano na dożywocie. Borowski napisał swoje opowiadanie w czasie, gdy tej niegodziwej kobiecie Amerykanie złagodzili wyrok. Jego bohater, komendant więzienia, odwiedza Elzę w celi, informując ją, szczerze zmartwiony, że odnaleziono abażury (które zlecała wykonywać ze skóry więźniów) i że w związku z tym zostanie powieszona. Oświadcza też, że chciałby ją posiąść. Intencja jest zdumiewająca: „Chciałbym ustanowić rekord [...]. Niektórzy [amerykańscy żołnierze - przyp. A.M.] zbierali trofea wojenne, ale było ich zbyt wielu, nikt się nie wyróżnił. [...] Spałem z dziewczętami narodów wyzwolonych, ale każdy to robił. Chcę być jedynym

18 Zob. np. S. Kowalski Dzień Schonungu. Z buchenwaldzkiego pamiętnika, "Za Wolność i Lud" 1949, $\mathrm{nr}$ 4, s. 8-9 (są to beletryzowane wspomnienia, przypominające, co znamienne dla literatury socrealistycznej, powiastkę dla młodzieży); T. Witek Powstanie w Buchenwaldzie. Pod sztandarem proletariackiego internacjonalizmu, "Za Wolność i Lud” 1950, nr 7, S. 12-13, 22. 
Amerykaninem, który miał kobietę zbierającą abażury ze skóry ludzkiej"19. Komendant dopiął swego. W efekcie, jak czytamy w zakończeniu opowiadania, „Frau Elza zaszła w ciążę, została zwolniona z więzienia i w niedługim czasie rekord Amerykanina upadl"20. Naładowane sarkazmem, intelektualnie i artystycznie miałkie opowiadanie Borowskiego uderza, w czasie, gdy tężeje zimna wojna, w Amerykanów, piętnowanych przez władze komunistycznej Polski jako sojusznicy „zachodnioniemieckich faszystów”.

Tego rodzaju manipulacje stają się około 1956 roku nieco subtelniejsze. Nie powoduje to jednak istotnej zmiany w literackim wizerunku Buchenwaldu, ponieważ do roku 1989 jest on kształtowany głównie przez literatów - i zarazem byłych więźniów tego obozu - reprezentujących orientację prokomunistyczną, w szczególności przez Czesława Ostańkowicza i Zygmunta Zonika. Obaj należeli do obozowego ruchu oporu. Po wojnie opublikowali po kilka książek, głównie wspomnień i opowiadań wywiedzionych z obozowych doświadczeń. W beletryzowanych wspomnieniach Straszna góra Ettersberg z 1968 roku Ostańkowicz stwierdza:

Hitlerowskie obozy koncentracyjne mają bogatą literaturę martyrologiczną. Nie mają natomiast literatury walki, jaka toczyła się przez pięć lat nie tylko w cieniu krematorium i obok sal tortur, ale również w halach zakładów wojennego przemysłu Trzeciej Rzeszy [...]. Brak książek opowiadających o tym polskiemu czytelnikowi [...] jest tym bardziej przykry, iż polscy więźniowie polityczni zawsze znajdywali się wśród najbardziej odważnych, zaangażowanych, oddanych sprawie ludzi. [...] O tej międzynarodowej, demokratycznej, antyfaszystowskiej konspiracji chciałbym opowiedzieć czytelnikowi tej książki. ${ }^{21}$

Podobny cel Ostańkowicz realizował, nieco wcześniej, w opowiadaniach z tomów Czarna z komanda Bayer, Dziwnynormalny świat i Bagaże petne niepokoju²2. Michał Głowiński, recenzent pierwszego z nich, trafnie wychwycił podstawowe znamię nieskomplikowanych, jednowymiarowych i przeestetyzowanych

19 T. Borowski Rekord, w: tegoż Opowiadania z ksiq̨żek i z gazet, PIW, Warszawa 1949, s. 85-86.

Tamże, s. 86-87.

C. Ostańkowicz Straszna Góra Ettersberg, s. 5-7. dania, Wydawnictwo Łódzkie, Łódź 1962; Bagaże pełne niepokoju, Wydawnictwo Poznańskie, Poznań 1966. 
opowiadań Ostańkowicza: „Niedawne konflikty łatwo poddają się heroizującej mitologizacji" ${ }^{\prime 2}$. Te same cechy, zwłaszcza heroizm i schematyzm, widoczne są w utworach Zonika. Jest on nie tylko współautorem najobszerniejszego polskiego opracowania dotyczącego Buchenwaldu, znamiennie i adekwatnie zatytułowanego: Walczacy obóz Buchenwald, lecz także autorem beletryzowanych wspomnień obozowych Opowieści z nieprawdopodobnego rewiru $^{24}$. Beletryzacjami są również, opublikowane w popularnej serii „Żółty Tygrys", trzy jego książeczki: Tajna radiostacja, Wiedźma z Buchenwaldu i Strzaty spod krematorium ${ }^{25}$. Liczne wątki i ujęcia zawarte w Opowieściach... i w „tygrysach" są ze sobą zbieżne. W każdej z nich podkreślany jest aktywizm i wieńczące działalność, kierowanego przez komunistów, obozowego ruchu oporu zwycięskie powstanie.

Buchenwald istnieje w literaturze polskiej jednak nie tylko dzięki byłym więźniom. Innymi źródłami tego motywu są rodzinne archiwa pisarzy, zawierające pamiątki (zwłaszcza korespondencję) po zamordowanych w tym obozie bliskich, oraz odbywane przez literatów wycieczki do Weimaru, zazwyczaj połączone z odwiedzinami miejsca pamięci Buchenwald. Oba te źródła są często ze sobą splecione, podobnie jak odzwierciedlające je motywy literackie.

Z pierwszym przypadkiem, motywem bolesnych pamiątek, ujętym samoistnie, mamy do czynienia rzadziej. Jego przejawem są m.in., stanowiące dyptyk, wiersze Anny Leonhardowej z 1976 roku: „Zdrów irześki” - kartka z Buchenwaldu i Urzędowe zawiadomienie $e^{26}$. Zamieszczone pod nimi dopiski: "Jasło 1941" i "Jasło 31.III.1942", bynajmniej nie wskazują miejsca i daty powstania utworów, lecz dwa fakty: wzbudzające radość otrzymanie od bliskiej osoby kartki z Buchenwaldu, z otwierającą ją obowiązująca, złudną formułą: „Ich bin gesund...", i nadejście po niej, wywołującego rozpacz, zawiadomienia o śmierci: „gestorben ist”, z dodaną jedną z „urzędowych” chorób, a raczej formuł: „lungenoedem” (na obrzęk płuc).

Znacznie częstszą niż przeglądanie rodzinnych pamiątek przyczyną pojawienia się w literaturze polskiej Buchenwaldu jest wycieczka do utworzonego

23 M. Głowiński Pozory autentyku, "Twórczość” 1959, nr 3, s. 169.

24 Z. Zonik Opowieści z nieprawdopodobnego rewiru, Iskry, Warszawa 1974.

Z. Zonik Tajna radiostacja, Wydawnictwo MON, Warszawa 1967; Wiedźma z Buchenwaldu, Wydawnictwo MON, Warszawa 1973; Strzały spod krematorium, Wydawnictwo MON, Warszawa 1974.

26 A. Leonhardowa „Zdrów i rześki” - kartka z Buchenwaldu; Urzędowe zawiadomienie, „Życie Literackie" 1976, nr 18, s. 6. 
na terenie byłego obozu miejsca pamięci. Bodaj pierwszymi z goszczonych tutaj polskich literatów byli dwaj członkowie polskiej delegacji uczestniczącej w manifestacji byłych więźniów i „obrońców pokoju”, zorganizowanej 11 kwietnia 1954 roku: Teofil Witek i Gustaw Morcinek ${ }^{27}$. Ze zwiedzania miejsca pamięci zrezygnowała natomiast, uczestnicząca rok później w weimarskich uroczystościach poświęconych Fryderykowi Schillerowi, Maria Dąbrowska. Pozostawiła jednak, w wydanych w 1956 roku Szkicach z podróży, istotny dotyczący Buchenwaldu i Niemców zapis:

W programie jest i zwiedzenie dawnego obozu hitlerowskiego w $\mathrm{Bu}-$ chenwaldzie. Nie jadę na wycieczkę do Buchenwaldu. Dość mi, że wiem, i dość mi, że pamiętam... Ale szanuję ludzi, którzy nie wzdragają się wciąż przypominać sobie i światu, że, jak pisze Peter Nell, to są rzeczy, „które zrobili Niemcy"! Nie wszędzie pokazywano by ludziom ślady własnych grzechów i zbrodni. Wprawdzie to komuniści pokazują zbrodnie swoich śmiertelnych wrogów. Ale pokazują je obcym, na ziemi będącej wspólną ojczyzną i komunistów, i hitlerowców. To wymaga szczególnego połączenia męstwa z dumną i twórczą skruchą. Nie każdy nazywający się wrogiem hitleryzmu na to by się zdobył. ${ }^{28}$

Z eksponowanym zarówno w twórczości powstającej w obozie, jak i w utworach późniejszych, „antytetycznym” motywem Buchenwald - Weimar (barbarzyństwo - kultura) ${ }^{29}$ sprzęgnięte bywają w literaturze polskiej dwie, często zamieniające temat Buchenwaldu w pretekst, kwestie: po pierwsze, jak mogło w kraju Goethego dojść do aktów skrajnego barbarzyństwa, i po drugie: kim dzisiaj są Niemcy, czy się zmienili... Druga z nich odgrywała rolę o tyle ważną, że mimo deklarowanych przez Polskę i NRD przyjacielskich stosunków wschodnioniemieckie państwo postrzegane było w PRL (rzecz jasna, w stopniu jeszcze większym dotyczy to RFN) jako zagrożenie dla jej „ziem odzyskanych”. Nawiasem mówiąc, „łączącą” oba państwa „granicę pokoju i przyjaźni" ich obywatele przekraczali sporadycznie. Do 1972 roku czynili to głównie w ramach oficjalnych delegacji - zwłaszcza twórców kultury

Zob. „Aby nigdy więcej nie było obozów śmierci”. Międzynarodowe Spotkanie w Buchenwaldzie, "Za Wolność i Lud" 1954, nr 4, s. 22. 
i przedstawicieli stowarzyszeń kombatanckich. Dobrą okazją zarówno dla jednych, jak i drugich było odsłonięcie w 1958 roku założenia memorialnego Nationale Mahn- und Gedenkstätte Buchenwald.

Plonem tego typu odwiedzin jest m.in. reportaż Stefana Otwinowskiego Weimar i okolica z 1958 roku. Zestawiwszy w nim „najkulturalniejsze małe miasto świata" z pobliskim „obozem śmierci”, autor stawia sobie pytanie: „jak to się stało? Czy na czas owych zbrodniczych praktyk wyludniło się owo kulturalne, spokojne miasto?", aby następnie, w dalszej części podróży (i tekstu), zadać je przygodnie spotkanym Niemcom. Udzielona przez jednego z nich odpowiedź: „Wiedzieliśmy i nie wiedzieliśmy, rozmiarów nikt nie znał... Tu był inny terror niż u was - terror paraliżujący"30, nie wydaje się Otwinowskiemu satysfakcjonująca. Wyrazem większego dystansu, zgoła nieufności, jest opublikowane rok później opowiadanie Seweryny Szmaglewskiej Niepostuszny w Weimarze ${ }^{31}$. Bardziej otwarty, pojednawczy stosunek do „wschodnich” Niemców widoczny jest w innych utworach, m.in. w reportażu Wojciecha Natansona „Śpiewające konie” Buchenwaldu z 1962 roku $^{32}$, w wydanym pięć lat później opowiadaniu Janusza Koniusza Wycieczka ${ }^{33}$ i w wierszach Eugeniusza Wachowiaka z tomu Turyngia z 1970 roku, zwieńczonego budującym przesłaniem: „Oto idę spokojny / ulicą Schillera / rozmawiam po polsku / w teatrze w kawiarni / i toast podnoszę // Na sto lat najbliższych / a chce się na zawsze / dla synów i wnuków / być tu / jak wśród swoich"34.

Inaczej niż Wachowiak odniósł się do Buchenwaldu, a raczej go spożytkował, Bohdan Urbankowski, syn więźnia tego obozu, w opublikowanym w 1972 roku tomie poetyckim Gtosy.Z cyklu „Umarliz Weimar-Buchenwald”, przypominającym tyleż gatunek, jakim jest rozmowa zmarłych, co Antologię Spoon River Edgara Lee Mastersa. Niewiele jest w tej książce dotyczących Buchenwaldu "rekwizytów” - poza wzmianką o „buchenwaldzkiej drodze”, Oddziale Patologii, amerykańskich czołgach i amerykańskich żołnierzach pędzących weimarczyków „w stronę Buchenwaldu”. Tytułowy Weimar-Buchenwald jawi się jako wcielenie każdego obozu koncentracyjnego i jednocześnie obozu zagłady, z takimi atrybutami, jak komora gazowa, palacze trupów czy ofiary,

S. Otwinowski Weimar i okolica..., „Życie Literackie” 1958, nr 48, s. 7.

S. Szmaglewska Nieposłuszny w Weimarze, „Nowa Kultura” 1959, nr 15, s. 1, 7.

W. Natanson „Śpiewające konie” Buchenwaldu. Notatki z NRD, „Życie Literackie” 1962, nr 45, s. 1-2.

J. Koniusz Wycieczka. Opowiadanie, "Życie Literackie” 1967, nr 3, s. 8-9.

E. Wachowiak Gasnq̨ niepokoje, w: tegoż Turyngia, PIW, Warszawa 1970, s. 90. 
wśród których są mężczyźni, kobiety i dzieci. Ukazany świat bardziej więc niż do podweimarskiego kacetu podobny jest do Birkenau. A nawet więcej: to świat zamieniony w ziemskie piekło. Podmiot mówiący wiersza T. Borowski po trzykroć stwierdza: „I to też jest świat”35. To właśnie Borowski zdaje się patronować dywagacjom Urbankowskiego o świecie, w którym pozacierały się, stanowiące fundament zachodniej cywilizacji, kategorie etyczne i zapadła się idea humanitas. Prowadzą je, w jego imieniu, więźniowie i obozowi funkcjonariusze, a także okoliczni mieszkańcy, weimarczycy. Niektóre z tych postaci autor wyposażył w znaczące nazwiska: Strauss, Pound, Goeth. Ostatnie z nich przywodzi na myśl tyleż wielkiego niemieckiego poetę, co komendanta KL Plaszow, Amona Götha. Inny zmarły, A. Lange, którego nazwisko odsyła do Antoniego Langego, polskiego poety zafascynowanego filozofią Nietzschego, stwierdza: „W tym świecie, z którego zdarto horyzonty, / nie było wolnych od winy, / winę wciskano nam w zęby jak kawałek chleba, jak powietrze, / kamienie nie były niewinne / i ptaki z nienawiścią omijały nasz obóz"36.

Książka Urbankowskiego należy do dokonań satysfakcjonujących zarówno pod względem intelektualnym, jak i estetycznym. Niestety nie da się tego samego powiedzieć o kolejnych, rozbudowywanych edycjach Głosów, z których ostatnia dotąd, czwarta, ukazała się w 2018 roku³. Urbankowski, m.in. poprzez dodanie "głosów" polskich patriotów i księży (więźniów nie tylko Buchenwaldu, lecz i Auschwitz), wierszy imitujących donosy, których autorami są komuniści, oraz „głosów” prezentujących komunistów w sposób karykaturalny, upraszcza, ujednoznacznia, w duchu narodowo-katolickim i martyrologicznym, to, co zarówno w obozie koncentracyjnym, jak i w pierwszym wydaniu Głosów było skomplikowane, nieoczywiste, często niejednoznaczne. Dezawuowanie przez poetę komunistycznej narracji o Buchenwaldzie, połączone z ujawnieniem faktów w niej przeinaczanych lub wypartych (autor czyni to samo w formie dyskursywnej w dołączonych do tomu autokomentarzach), bez wątpienia poznawczo pobudzające, cenne, skutkuje niestety - przez nadmiar ideologicznego zaangażowania - fundowaniem nowego mitu, nowej mononarracji. W zawartych w książce autokomentarzach Urbankowski wspomina np. o bezwzględnym rozprawianiu się więźniów-komunistów z polskim oficerami, o ich dobrowolnym wstępowaniu w 1944 roku do niemieckiej armii

B. Urbankowski T. Borowski, w: tegoż Głosy. Z cyklu „Umarli z Weimar-Buchenwald”, Wydawnictwo Lubelskie, Lublin 1972, s. 61-62. 
i o uratowaniu przez nich kilkuletniego polsko-żydowskiego dziecka - jak się po latach okazało, kosztem kilkunastoletniego więźnia-Cygana ${ }^{38}$.

Motyw Buchenwaldu w literaturze polskiej jest, jak widać, silnie zideologizowany. Pojawia się zwykle jako pretekst dla deklaracji światopoglądowych i podejmowania aktualnych kwestii społeczno-politycznych. Wyjątków od tej reguły z lat 1945-1989 wskazać można niewiele. Utworem, w którym Buchenwald stanowi, by tak rzecz ująć, motyw „czysty”, zasadniczo neutralny, "niezaangażowany”, jest emigracyjne opowiadanie Lurczyńskiego Księżniczka Buchenwaldu z 1961 roku. Bohaterką tej fabulacji jest prosta, uboga Francuzka, odwiedzająca po wojnie Buchenwald, w którym zginął jej mąż. Słuchaczem prezentowanej przez nią opowieści o odwiedzinach tego miejsca i jednocześnie narratorem nadrzędnym utworu jest były więzień Buchenwaldu, który jak się okazuje, pamięta męża bohaterki, półobłąkanego, umierającego, gwiżdżącego stale „melodię radosnej żwawej piosenki, w której było wszystko - i słońce Południa, i wino, i taniec, i śmiech"39. W opowiadaniu tym kontrapunktem dla Buchenwaldu nie jest, czego można by się spodziewać, Weimar z jego wzniosłymi konotacjami kulturowymi, lecz uwznioślone, zwyczajne - zamordowane - życie i jego piękno.

Po roku 1989 Buchenwald pojawia się w literaturze polskiej sporadycznie. Oprócz rozszerzonej edycji Głosów udało mi się znaleźć tylko trzy utwory dotyczące tego obozu: dwa eseje i wiersz. Ujmują one Buchenwald pretekstowo. Inspirację esejów stanowiła wycieczka do miejsca pamięci, w przypadku wiersza była nią fotografia.

W eseju Jacka Dehnela Dąb Goethego z 2007 roku Buchenwald, a ściślej, jeden z jego „emblematów”, "dąb Goethego", jest pretekstem do rozważań o człowieczej potrzebie sensu, wydobywanego nawet z „resztek”, czego przejawem jest „półmetrowy pień, dziś otoczony [w buchenwaldzkim miejscu pamięci - przyp. A.M.] kamiennym kręgiem i dalej czczony jako dąb, który

38 Do polskich tekstów wspomnieniowych "dezawuujących" komunistów, notabene nielicznych, należy Pamiętnik czasu pogardy księdza Franciszka Dziaska (Wydawnictwo UAM, Poznań 2005). Czytamy tu m.in.: "Na kilkaset komunistów w obozie na palcach jednej ręki można by policzyć tych, którzy zachowali postawę humanitarną" (s. 55). Bardziej wyważone ujęcie, wszakże niestroniące od wzmianek o skandalicznym zachowaniu niektórych komunistów, prezentuje socjaldemokrata (i chrześcijanin) Eugen Kogon w monografii Państwo SS. Organizacja i funkcjonowanie niemieckiego obozu koncentracyjnego, przeł. I. Ewertowska-Klaja, Replika, Zakrzewo 2017, s. 332-333. Zob. ponadto W. Pomianowski Buchenwald odzierany z mitów, "Rzeczpospolita” 1995, nr 92, s. 23. 
stał się pniem"40 Tenże pień to (nieistniejące dziś) drzewo - konkluduje Dehnel - „ciągle rośnie, rośnie w nas. I im bardziej go nie ma, tym więcej go

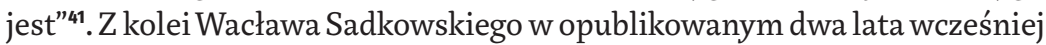
eseju Oświęcim z perspektywy Buchenwaldu zajmuje kwestia manipulowania historią: „Niedługo po zakończeniu wojny - wspomina - przeczytałem [...] w którejś z gazet opowieść o tym, jak to młody oficer radziecki wkroczył do [znajdującego się w Weimarze - przyp.A.M.] grobowca, w którym spoczywają zwłoki Goethego i Schillera, zasalutował im i oznajmił: Gospoda, wy swobodnyje (Panowie, jesteście wolni). Był to czas, w którym nie tylko kilkunastoletni uczniowie (a do takich wtedy należałem) zapragnęli uwierzyć, że to prawda"42.

O tym, że prawda, w tym prawda o Buchenwaldzie, jest zawsze cząstkowa i nie całkiem uchwytna, bo modelowana przez rozmaite dyskursy, zwłaszcza ideologie ${ }^{43}$, świadczy też opublikowany w 2005 roku wiersz Piotra Matywieckiego, zaczynający się od słów: „Wywleczeni na słońce”"44. Jego bohaterami są uwiecznieni na propagandowej fotografii nazistowskiej z 1938 roku upośledzeni żydowscy więźniowie Buchenwaldu ${ }^{45}$. Poeta, dokonując precyzyjnej deskrypcji zdjęcia, odnajduje w nich dumę, inteligencję, heroizm, cechy stanowiące, wbrew intencji zleceniodawców fotografa, o ich człowieczeństwie. Wiersz ten, intrygujący i artystycznie udany, jest znamienny z co najmniej dwóch powodów. Po pierwsze, należy do niewielu w literaturze polskiej utworów przywracających pamięć o zapomnianej przez dziesięciolecia grupie ofiar nazistowskiego ludobójstwa - osobach upośledzonych umysłowo i chorych psychicznie. Zarazem, po drugie, dokonuje się w nim swoiste wchłonięcie tematyki obozowej przez tematykę Holokaustu. Tematem tego wiersza nie jest ani eksterminacja osób psychicznie chorych, ani obóz koncentracyj-

40 J. Dehnel Dąb Goethego, „Odra” 2007, nr 9, s. 56.

41 Tamże. W. Sadkowski Oświęcim z perspektywy Buchenwaldu. Notatki z podróży, "Akcent” 2005, nr 1, s. 43. Pomijam tutaj jego (przez dziesięciolecia przemilczany) "dalszy ciąg", tj. funkcjonujący w latach 1945-1950 w tym samym miejscu, utworzony przez Sowietów Obóz specjalny NKWD nr 2, w którym straciło życie około 7000 osób, zarówno hitlerowców, jak i wszelkich osób uznanych za wrogów nowego porządku. (Liczbę ofiar obozu nazistowskiego i jego podobozów szacuje się na ponad 56000$)$. P. Matywiecki *** Wywleczeni na słońce..., w: tegoż Ta chmura powraca, Wydawnictwo Literackie, Kraków 2005, s. 61-62. collections.ushmm.org/search/catalog/pa1051047 (25.03.2020). 
ny; jest nim zagłada Żydów i niemożność jej pojęcia. Utwór ten, niezależnie od wpisanych weń przez autora szlachetnych intencji, koresponduje z coraz powszechniejszym na Zachodzie mniemaniem, że wyłącznymi ofiarami niemieckich nazistowskich obozów koncentracyjnych byli Żydzi. Oczywiście jest ono fałszywe, podobnie jak, często spotykane, ujmowanie Losu utraconego Imre Kertésza jako dokonania wyłącznie literatury Holokaustu, gdy tymczasem powieść ta należy równocześnie do literatury obozowej.

Józefa Szajnę, malarza i reżysera, bez wątpienia najwybitniejszego polskiego artystę „uformowanego" przez Buchenwald (a także Auschwitz, w którym więziono go wcześniej), irytowało, gdy publiczność, z którą się spotykał, widziała w nim Żyda. Nie dlatego, że był antysemitą (zapewne nim nie był), lecz w imię oczywistej prawdy, że więźniami kacetów byli przedstawiciele wielu narodów. W jednym z wywiadów Szajna wspomina: „Kiedy realizowałem Replikę [spektakl teatralny - przyp. A.M.] w Izraelu, okazało się, że Izraelczycy nie wiedzieli o tym, że Polacy także siedzieli w obozie w Oświęcimiu. [...] Rok temu byłem z wystawą w Bostonie, miałem spotkania z publicznością i ciągle musiałem się tłumaczyć, że nie jestem Żydem, bo wszyscy uważali mnie za Żyda, skoro byłem więźniem Auschwitz"46.

Przejdźmy do konkluzji. Na tle polskiej literatury lagrowej liczba utworów podejmujących temat Buchenwaldu prezentuje się skromnie ${ }^{47}$. Nie ma wśród nich arcydzieł czy choćby utworów wybitnych. Zdarzają się jednak dokonania pod względem poznawczym lub artystycznym interesujące. Do tych pierwszych należą, zapoznane przez badaczy nazistowskich obozów, przedwojenne reportaże Nogaja i wspomnienia Wójcika oraz, będące same w sobie szczególnym świadectwem, komponowane w Buchenwaldzie wiersze. Do drugich zaliczam pierwodruk cyklu poetyckiego Głosy Urbankowskiego i wiersz Matywieckiego. Między jednymi i drugimi sytuuje się rewelatorski, nie tylko na tle literatury polskiej, dramat Stara Gwardia Lurczyńskiego, ukazujący tzw. szarą strefę (określenie Primo Leviego). Pozostałe utwory są interesujące głównie jako wyraz ideologicznego i politycznego zaangażowania (widocznego nie tylko w okresie Polski Ludowej, choć wtedy przede wszystkim), a także

46 Koniec pojednania - mój testament. Rozmowa z Józefem Szajną, rozm. E. Likowska, "Przegląd” 2005, nr 4, www.tygodnikprzeglad.pl/koniec-pojednania-8211-moj-testament/ (25.08.2019). kła Buchenwaldu doznało wielu więźniów Polaków; literatura na ten temat - w porównaniu do relacji z innych obozów - jest u nas jednak uboga i trudno dostępna" (). Masłowski Posłowie, w: J. Osuchowski Zapomnieć nie mogę. Wspomnienia więźnia małego obozu w Buchenwaldzie, Wydawnictwo Literackie, Kraków 1975, s. 113). Konstatacja ta nie straciła na aktualności. 
społecznej i indywidualnej pamięci oraz wrażliwości. Buchenwald jako temat literacki nie był, nie jest i zapewne nigdy nie będzie w stanie „konkurować” z obozami usytuowanymi na ziemiach polskich, zwłaszcza z Auschwitz, stanowiącym centralny symbol polskiej martyrologii, a zarazem symbol Szoa i, jak to ujął Kertész, były więzień Auschwitz i Buchenwaldu, „ponadczasową przypowieść naznaczoną piętnem nieprzemijalności"48.

\section{Abstract}

\section{Arkadiusz Morawiec}

UNIVERSITY OF ŁÓDŹ

Konzentrationslager Buchenwald, Post Weimar (in Polish Literature)

In the context of the Polish literature devoted to Nazi German concentration camps, the works dealing with the subject of Buchenwald are rather scarce. None of them are masterpieces or at least exceptional literary works. Some, however, are interesting cognitionor artistic-wise. The former include the prewar reportages by Stanisław Nogaj entitled Za drutami i kratami Trzeciej Rzeszy (Behind the fences and bars of the Third Reich) and the memoirs of Władysław Wójcik entitled Byłem w piekle... (I've been to hell...), overlooked by the researchers of the Nazi camps, and the poems written in Buchenwald, which are an interesting account in their own right. I would include among the latter the first edition of Bohdan Urbankowski's poetry cycle Głosy (The Voices) and Piotr Matywiecki's poem $*$ * Wywleczeni na stońce... ( ${ }^{*} *$ Dragged into the sun). Situated between the two groups is Mieczysław Lurczyński's revelatory - not just in the context of Polish literature - drama Stara Gwardia (The Old Guard), which depicts the so-called "grey zone" (to use the term of Primo Levi).The remaining works are interesting mostly as manifestation of ideological and political involvement (visible not just in the Polish People's Republic period, although mostly then), as well as of collective and individual memory and sensitivity. As a literary theme, Buchenwald has not been and likely never will be able to "compete" with camps located in the Polish territories, especially with Auschwitz-Birkenau, which is a central symbol of Polish martyrology and of Shoah, also being, in the words of Imre Kertész,"a timeless tale marked with the stigma of non-transience".

\section{Keywords}

Polish literature, concentration camp literature, Konzentrationslager Buchenwald

48 I. Kertész Nieprzemijalność obozów, w: tegoż /ęzyk na wygnaniu, przeł. E. Sobolewska, W.A.B., Warszawa 2004, s. 33. 